\title{
A Narration: 20th v/s 21st Century: Pandemic v/s Another Pandemic: Virus v/s Another Virus (Spanish Flu V/S COVID-19)
}

\author{
A. Saulat and A. N. Jafri
}

\section{ABSTRACT}

Pandemic leads to major mortality and morbidity. Many pandemics occur over the centuries, but the mother of all pandemic was "Spanish Flu" and nowadays we are facing another huge uncontrollable "Covid 19" pandemic of the current century. The purpose of this comparative review is to help and provide guidance for frontline medical staff in dealing with this current outbreak to differentiate and seek information with the previous pandemic and get knowledgeable guidance for future dealings of COVID-19. Peerreviewed literature on the outbreaks of infectious disease has steadily increased in recent years, but the major pandemics should be compared to find out the similarities and differences. To do so, we provide step by step contents of both diseases.

Published Online: January 8, 2021

ISSN: $2593-8339$

DOI: $10.24018 /$ ejmed.2021.3.1.594

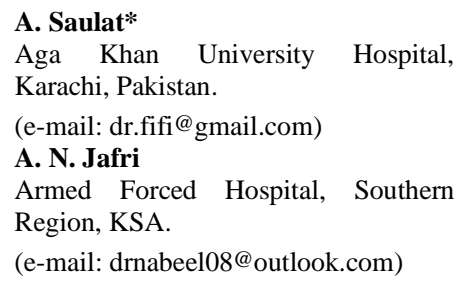

*Corresponding Author

Keywords: infection control and management, respiratory illness, SARS CoV-2, Spanish Flu.

\section{INTRODUCTION}

Throughout history, nothing has executed human beings more than infectious diseases. The deadly "Spanish flu" pandemic had last from January 1918 to December 1920. The mortality was estimated to have been anywhere 17 million to 50 million [1], [2]. It was late December 2019, hospitals in Wuhan, Hubei, China, reported a cluster of cases with pneumonia of unknown cause, another pandemic, attracting great attention worldwide. The number of PCR-confirmed cases has touched the threat level and within one month, WHO declared COVID-19 to be a Public Health Emergency of International Concern (PHEIC) and declared an epidemic has occurred. We reviewed the published clinical features, symptoms, complications, and treatments of patients with Spanish flu and COVID-19 to help health workers around the world combat the current outbreak.

\section{LITERATURE SEARCH}

This narrative review discusses the relevant literature, including updated studies, and the implications for practice concerning Spanish flu and COVID-19 infections. We performed a literature search using Pub Med and UpToDate. The search was restricted to articles between 1997 and 2020. Keywords used were "COVID-19," "2019 novel coronavirus", "SARS-CoV-2", "2019-nCoV", "Wuhan coronavirus" "Spanish Flu", "1918 H1N1", "Pandemic".

\section{HISTORY}

Spain is not the geographical origin of the Spanish flu. The Spanish government was the first one to accept that unusual and strange pathogen, since then the name stuck to it. The outbreak occurred in three waves. It was World War I, during which the first wave started in early March 1918 [17]-[19]. It was benign comparatively and resembled typical flu epidemics; sick and elderly were at risk mostly, although young and healthier communities recovered easily. However, in August 1918, the second wave of a more lethal type of disease had fully emerged. Pneumonia often developed rapidly, with high mortality within two days after the first indications of the symptoms. When the second wave began in, the Spanish flu had mutated to a much deadlier form when it reached France and the United States [20]. The third wave occurred in winter, and by the spring the virus had over its course [21]. About half of the deaths were among the younger age group, which was an unusual mortality age pattern recognized with the latter two waves.

\section{A. End of Deadliest Pandemic}

The Spanish flu pandemic came to an end by the summer of 1919, as those that were infected either developed immunity against the virus or no more. Despite the very high mortality with this influenza pandemic, the memories began to fade away and to be called as "forgotten pandemic". Over time, the public awareness wane off until the new bird flu and other pandemics recalled the memories once again in the 1990s and 2000s, although with not much cruelty. 


\section{B. Beginning of New Pandemic}

It was on 31 Dec. 2019, when China, the most populated country of East Asia, was informed to WHO regarding mysterious pneumonia of unknown etiology [22], [23].

On 7 Jan 2020, from the seafood market in Wuhan city, Chinese research authorities mentioned that they isolated a new virus; named as 2019-nCoV, that closely related to bat coronavirus [24], Pangolin coronaviruses [25] and SARSCoV. Official names have been announced latter for the virus responsible for COVID-19 ("coronavirus disease") and the virus is "Severe acute respiratory syndrome coronavirus-2" (SARS-CoV-2) [26], [27].

Considering this deadly virus is of zoonotic origin as many of the cases had linked to the seafood wholesale market in China [28]-[30].

On 30 January 2020, Public Health Emergency of International Concern had declared the outbreak [31], [32].

As per WHO, too- date 29 November 2020, there have been $61,869,330$ confirmed cases of COVID-19, including $1,448,896$ deaths, reported to WHO [33].

\section{ETIOLOGY}

According to the Centers for Disease Control and Prevention, there are $18 \mathrm{H}$ subtypes and $11 \mathrm{~N}$ subtypes identified with variations [34]. But $\mathrm{H} 1, \mathrm{H} 2$, and $\mathrm{H} 3$ have substantial human-to-human transmission [35].

H1N1 virus with genes of avian origin was identified as Spanish flu, a member of the family Orthomyxoviridae (a group of RNA viruses) with 2 surface antigens (hemagglutinin $(\mathrm{H})$ and neuraminidase $(\mathrm{N})$. These antigen shows drift by mutation. Antigenic drift produces new strains of H1N1 that causes epidemic [36], [37]. During the last century, there were four pandemics of influenza strain had been observed; the H1N1 Spanish flu (1918), the H2N2 Asian flu (1957), the H3N2 Hong Kong flu (1968), and the H1N1 swine flu (2009).

Coronaviruses are enveloped RNA viruses. Not so often, Animal coronaviruses can spread to humans and subsequently spread among humans, SARS and MERS were the examples. SARS-CoV-2 is among the Sarbecovirus subgenus of the family Coronaviridae, known to infect humans. This virus has been isolated and found to be similar to SARS-like coronaviruses from bats, but it is found to be different from SARS-CoV and MERS-CoV [38], [39]. There are two subtypes (L and S) of the SARS-CoV-2 strains found in China. The $\mathrm{L}$ type was found to be more prevalent and more aggressive during the early stages of the outbreak in Wuhan City [40]. It has been confirmed that the virus binds to the angiotensin-converting enzyme-2 (ACE2) receptor in humans, which suggests similar pathogenesis to SARS [41], [42]. However, there is a unique structural feature of the spike glycoprotein receptor binding domain which offers a higher binding affinity of SARS-CoV [43]. A furin-like cleavage site does not exist in other SARS-like coronaviruses [44]. Because of the ACE2 expression level, lungs, heart, esophagus, kidneys, bladder, and ileum are considered more vulnerable to SARS-CoV-2 infection [45]. And due to a down regulating ACE2 receptor level, it induces acute respiratory distress syndrome and myocarditis [46].

\section{PReVAlence}

Despite poor or nearly absent data for many countries, the pandemic mostly killed young adults. It was thought to be due to the cytokine storm (an overreaction of the immune system). This may be the reason for its surprising effect on younger and healthier people [47]-[50]. 99\% of deaths in the U.S. occurred in people under 65 , and nearly half of deaths were in young adults between 20 to 40 years old [51].

Data from the largest case series in China found that $3 \%$ were aged around 80 years and more, $87 \%$ cases were aged around 30 to 79 years, $1 \%$ was around aged 9 years or less and, $1 \%$ was aged between 10 to 19 years. In this case series, $51 \%$ of patients were male and $49 \%$ were female. Healthcare workers were involved in $4 \%$ of cases with 23 deaths [53]. Children were infected less which accounts for only $1 \%$ to $5 \%$ as compared to adults, with the median age of 7 years [54].

\section{DiAGNOSIS}

To check Spanish flu virulence and understanding the deadly virus, reconstruction of the entire 1918 virus was begun in August 2005 [56] but there is no data available for the detection of H1N1 in past like nowadays (rapid molecular assays, RIDTs)

Detection of SARS-CoV-2 RNA by reverse transcriptionpolymerase chain reaction (RT-PCR) is the gold standard for the diagnosis of COVID 19 [57]. It is better in nasopharynx samples compared to throat samples [58].

There may be the availability of urgent and convenient detection of virus by saliva sampling, although it's not the gold standard [59].

There is also the detection of SARS-CoV-2 RNA in stool and blood [60] and it may be the marker of severity of illness [61].

\section{MODE OF TRANSMISSION}

Like any other influenza viruses known, Spanish flu was also transmitted from person to person through airborne respiratory secretions. World War I hastened the pandemic and as well as a denial by the government and public was not prepared to handle another problem [62].

The risk of transmission is thought to be greatest when patients are symptomatic since viral shedding is greatest at the time of symptom onset and declines over several days to weeks. Novel Coronavirus can spread with respiratory droplets, so the close contacts 1 to 2 meters (3 to 6 feet) [63] is recommended, while both sputum and saliva can carry the heavy viral load [64]-[66].

The virus can also stay prolonged in the air and can be the source of transmission [67]. Therefore, some have proposed that precautions should be used everywhere [68]. However, the proportion of SARS-CoV-2 transmission in the population due to asymptomatic or pre-symptomatic infection compared to symptomatic infection is unclear [69]. There is an estimate of one infected person may transmit and infect the other person of the population for COVID-19 is $2.2 \%[70]$.

The virus can survive on surfaces for up to 72 hours. Fomites, though not certainly, are suspected as the source of 
infectious particles [71].

There is the potential of fecal-oral transmission of this disease as a virus has been detected from stool sample [72]. Vertical transmission is less likely to occur based on little research data available [73].

\section{Clinical Manifestations}

Uncomplicated Spanish flu symptoms were quite similar to seasonal influenza as often described in the clinical records [74].

These symptoms include high fever, malaise, cough but muscle ache, vomiting, fatigue, and headache were also common. In contrast to seasonal influenza, epistaxis often appeared. In serious cases, cyanosis was described as the most important predictor of a worse outcome [75].

Complications like "Post influenza pneumonia" developed sooner after the onset of the influenza symptoms in most of the infected people. A prolonged duration of high fever was the first indication of a secondary infection [76]. Other most commonly reported pathological findings were endocarditis and hemorrhagic pulmonary disease. The mortality becomes evident within 9.6(SD 3.3) days [77]. The incubation period is around 14 days, with a median time of 4-5 days [78-[81]. The most contagious period of this virus is during the first three days with the start of symptoms although it can spread earlier [82]-[84]. There is a diversity of range of intensity of this disease reported so far. Fever is the main clinical manifestations of COVID-19 (90\% or more) then cough $(75 \%)$, and shortness of breath (50\%) [85]-[88]. Older individuals with co-morbidities can present with delayed onset of symptoms [89], [90].

There is some extrapulmonary or atypical clinical presentations are also noted like vomiting, and diarrhea before respiratory symptoms [91]. Headache, confusion, pink eye, conjunctivitis is also reported. Anosmia or ageusia before the onset of respiratory symptoms [92], [93]. Acute kidney injury of various severity is also seen with the critically ill patient, either due to the overall patient's critical illness or a direct effect of virus attack ACE2 receptors present on the kidney, although many types of research are ongoing [94], [95].

\section{COMPLiCATIONS}

Spanish flu initially misdiagnosed and due to its extremely high infection rate, complications and mortality became so high [96], [97].

The observed complication was hemorrhage from the nose and upper gastrointestinal. Bleeding from ears and petechial hemorrhage in the skin was also observed. Most of the death occurred due to secondary bacterial pneumonia [99].

Spanish flu has been linked to the outbreak of encephalitis lethargica in the 1920s [100].

There is an association between differences in age and prevalence of underlying conditions (cardiovascular disease, diabetes, chronic respiratory disease, hypertension, and cancer) with increased mortality associated with COVID-19 [101].

A high inflammatory response results in a variety of cardiovascular complications like myocarditis, heart failure, arrhythmias, acute coronary syndrome [102].

Cytokine release syndrome results in multiple-organ failure that leads to death [103]. ARDS was reported in 15\% to $33 \%$ of patients [104] and children are more prone to develop ARDS [105]. Critically ill patients may more likely to develop an acute liver injury, although it's not routinely seen [106].

There are high chances of thromboembolic complications in COVID-19 as it has prothrombotic properties [107].

$25 \%$ to $69 \%$ of patients have been reported with venous thromboembolism in severe COVID-19 [108].

Cerebrovascular thrombosis has been reported in a few patients younger than 50 years of age in New York [109].

Acute Guillain-Barre syndrome as initial presenting symptoms in a few patients with COVID-19 has been observed [110].

Acute kidney injury by the virus itself rather than in complicated disease is the emerging new finding and reported in $3 \%$ to $8 \%$ of patients in case series [111]-[113].

Secondary infections are also associated with COVID 19 and the major cause of morbidity and mortality [114]. A conclusion section is not required. Although a conclusion may review the main points of the paper, do not replicate the abstract as the conclusion. A conclusion might elaborate on the importance of the work or suggest applications and extensions.

\section{A. Reinfection or Immunity}

There are more upcoming researches about the immunity or reinfection. Initially, it was thought that there was no data concerning the possibility of re-infection after recovery. Clinical recovery has been correlated with the detection of IgM and IgG antibodies which signal the development of immunity [115], [116].

But as more researches are coming and the exploring of this surprising virus, new and future outcome can be predicted. Recently Geneva-based UN health agency stated that more evidence needed about the effectiveness of antibody-mediated immunity to guarantee the "risk-free certificate". WHO also stated that there is currently no evidence that antibodies produced in recovered patients are enough to keep them protected against re-infection.

\section{B. Long Term Effects}

As far as the limited data allow us to conclude the long term effects from past pandemics. It causes economic damage, individual behavioral changes; increased rates of physical disability displayed reduced educational attainment [117], [118].

Severe global socioeconomic effects like the cancellation of sporting, religious, political, and cultural events and panic buying result in widespread shortages of supplies [119]. Educational institutes have been closed [120]. Politically unstable countries have been facing increase political stresses. Pandemic control measures such as quarantines, curfew, and lockdown have sparked tension between citizens and states. 


\section{Control Measure}

Preventive measures are a powerful weapon. To prevent the influenza transmission, physicians and public Health Authorities of that time suggested many measures which included cleaning and disinfecting the mouth and nose areas with a mixture of oil and menthol or hydrogen peroxide, avoiding closed settings and direct contact with sick, eating a healthy diet, to ventilate the housing and good sleep and resting. These measures were simple but often hard to carry on [121], [122]. For Coronaviruses, there's currently no vaccine to prevent the disease (COVID-19) [124]. So recommended preventive measures include hand washing regularly for 20 seconds, with soap and water or alcoholbased hand rub, covering one's mouth when coughing, maintaining distance from other people (1 meter or 3 feet), and monitoring and self-isolation of people who suspect they are infected [125]. Contact isolation objects such as masks, gowns, and gloves are also recommended [126]. Transmission via ocular surface can be possible [127], so eye protection should also be considered. The virus is killed by household soap outside the human body, which dissolves its outer envelope [128], [129]. Health officials and authorities across the world have announced to implement quarantines, curfews and stay-at-home orders, workplace hazard controls, lock-down, and travel restrictions [130], [131]. Many household animals have been tested positive for COVID-19 but there is no evidence so far that animals can pass the pathogen to the humans [132], [133].

\section{MANAGEMENT}

In the 1940s, America licensed the first flu vaccine. So earlier to this, there was no preventive vaccine for Spanish flu either. In 1924, Red Cross assembled a team to assess the effectiveness of the treatments used for the biggest pandemic. Later the committee concluded that none of the drug treatments given or trials attempted during the pandemic had any proven effects on the influenza outbreak [134]. But the implementation of non-pharmaceutical interventions resulted in decreased peak mortality rates around 50\% [135].

When the Spanish flu hit, it was the time when World War I had left parts of America with a shortage of health workers. Physicians and scientists had no obvious knowledge of etiology and treatments. Symptomatic therapy was practiced like salicylates and quinine and codeine for cough. Complicated therapy was injecting with silver or platinum colloid solutions, digitalis, a camphor oil, or adrenaline. Alternative therapies were also tried. There was no consensus on the effectiveness of the perspiration method, which was thought to reduce mortality in Swedish hospitals [136]. Diphtheria treatments [137] and syphilis treatments [138] were also attempted. Heroin was used as a cough suppressant treatment [139].

Acetylsalicylic acid was used widely with digitalis but latter data showed that there was increased mortality observed with this regimen [140].

At present, most treatment is symptomatic and supportive for Covid-19 [141]. Many drugs are in different stages of being tested as treatments for the Covid-19. The drugs trials being tested, from flu treatments to failed Ebola drugs, to antimalarials and many more; like Antiviral EIDD-2801,
Japan flu drug (favipiravir or Avigan), A blood pressure drug (Losartan), an HIV drug combination drug Kaletra (a combination of lopinavir and ritonavir) [142], [143]. The first reported case with 2019-nCoV infection in the United States of America was treated with remdesivir [144]. A recent study conducted by the "front-line" health care providers combating COVID-19 in Wuhan indicated that systemic corticosteroid treatment did not show significant benefit [145]. Baricitinib has been suggested as a potential drug for the treatment in the hope that it might reduce the process of both virus invasion and inflammation [146], [147]. Steroids use are very common and several researches has been conducted and having good results on severe Covid-19.

Hydroxychloroquine and chloroquine are FDA proved for pre-exposure or post-exposure prophylaxis of SARS-CoV-2 infection as their research had been done on influenza in past studies [148], [149], [150], [151]. Convalescent plasma for the treatment of patients with COVID-19 is being used as well [152], [153]. Considering the mechanism through which this virus works in the human body, many researchers have given the idea that (ACE) inhibitors or angiotensin receptor blockers (ARBs) or NSAIDs may worsen COVID-19 but currently, no data are suggesting an association between COVID-19 clinical outcomes and the drug uses.

With CoVid 19, several efforts for the development of vaccines are ongoing, but as per WHO, initially it would take 18 months for the COVID-19 vaccines to be available. Huaxia. WHO says vaccines against novel coronavirus 18 months away [154], [155]. Inactivated or weakened virus vaccines, Protein-based vaccines, Viral vector vaccines, RNA and DNA vaccines have been studied but Interim analyses of phase 3 studies have been announced, through press releases, for four candidate COVID-19 vaccines. These are the mRNA platform candidates from Pfizer/Biontech and Moderna, the ChAdOx1 platform candidate from AstraZeneca, and the Ad26/Ad5 platform candidate from the Gamaleya National Centre. Preliminary point estimates of vaccine efficacy all exceed WHO Target Product Profiles and WHO draft EUL criteria. No safety concerns have been identified from the preliminary analyses. Uncertainties remain, however, since the full data have not yet been assessed by regulators nor have peer-reviewed manuscripts yet been published. It is estimated that about $60 \%$ of the world population must be vaccinated for the control of virus from spreading (herd immunity).

\section{DISCUSSION}

Ecology is changing; the spillover of viruses from natural hosts to humans continues to be escalating. SARS-CoV, MERS-CoV, H5N1, H7N9, Ebola, and emerging SARCoV2, highly lethal viruses should be alarming to the world. We should strive to reduce the probability of invisible viruses' devastating effects on human beings.

Comparability between Spanish Flu and Covid 19: Both diseases share animal hosting before infecting human hosts. Spanish flu virus genes suggested the deadliest wave of the outbreak came from a bird, while health experts suspect an animal hosted the COVID-19, although definite animal host has not been identified. There is an apparent dangerous mutation of both of these pathogens before transferring to 
humans. The infection rate of these viruses is another similarity as they are very rapid to spread. Spanish flu infected an estimated $1 / 3$ of the global population and COVID 19 is everywhere on the globe. Assuming the high mortality, we are going through for COVID 19, the death rate is estimated for Spanish flu is greater than $2.5 \%$. The mortality rate may be similar for the Coronavirus but the true case fatality rate remains to be determined based on new information but according to JAMA study published in February, the CFR is $2.3 \%$, which is almost the same to Spanish flu rate.

They may vary in many ways. Historic timing is the most important difference between the two pathogen diseases outbreak. Spanish flu is the mother of the pandemic because it coincided with World War 1, which spread the disease so quickly. Overcrowded army camps and hospitals made the flu more epidemic and people's focus was on war efforts mainly. In contrast, for Covid 19 many nations have travel restrictions and in lock downstate. National Geographic survey suggested that the Spanish flu wiped out the victims very rapidly, although Covid 19 takes a longer time.

The impact of Spanish flu can still be seen, as nearly all the human cases of influenza A are the descendants of it. But Covid 19 is so new that much information is yet to be discovered. During the current century, we benefit from modern resuscitation techniques and the treatment necessary to treat the complications of the disease while in the 20th century; scientific knowledge is not as advanced as today. Spanish flu was found to be more deadly for younger age groups. By contrast, coronavirus is more threatening to different age groups especially elderly and with co-morbid medical conditions.

The COVID-19 pandemic continues. During this, significant progress has been made in virus monitoring, its basic etiology, clinical treatment, drug testing, and efforts of the development of a vaccine. Chinese efforts and contributions from other countries in the world, we believe that this outbreak will subside soon with their occurrence and all the harms.

\section{CONClusion}

Despite the cruel scale of the Spanish flu as it killed more people in 24 weeks than HIV killed in 24 years. There were several outbreaks in decades like SARS in 2003, H1N1 in 2009, and now this Covid-19 era. The WHO asserts that the pandemic can be controlled.

The outbreak duration is uncertain and varies by location. With the strengthening of investigation of animal etiology, the storage of virulent pathogens normalization, reduction of wildlife contact, balancing the barriers between natural reservoirs, and human society will help to control these horrible events in the future. We have learned a lot of lessons from past outbreaks, that we can do competent monitoring and better prepared for the current situation. But meanwhile, we should beware of the subsequent latter waves of this current outbreak as happened with Spanish flu.

\section{REFERENCES}

[1] Rosenwald, Michael S. "History's deadliest pandemics, from ancient Rome to modern America".

[2] Frost WH. Statistics of influenza morbidity. Public Health Rep. 1920; 35:584-97.

[3] "La Grippe Espagnole de 1918" (in French). Institut Pasteur.

[4] K. Taubenberger, Ann Reid, Amy Krafft et al. Initial Genetic Characterization of the 1998 "Spanish' Influenza Virus. Science. Mar 1997; Vol 275, Issue 5307, pp 1793-1796.

[5] Kendal AP, Noble GR, Skehel JJ, Dowdle WR. Antigenic similarity of influenza A (H1N1) viruses from epidemics in 1977-1978 to "Scandinavian" strains isolated in epidemics of 1950-1951. Virology. 1978; 89:632-6.

[6] Barbara Jester et al. Readiness for Responding to a Severe Pandemic 100 Years After 1918. Am J Epidemiol. July 2018. 187(12): 25962602. DOI: $10.1093 / a j e / k w y 165$.

[7] P. Johnson and J. Mueller. Updating the accounts: global mortality of the 1918-1920 "Spanish" influenza pandemic. Bull. Hist. Med. 2002. 76(1): 105-115.

[8] Barbara Jester et al. Historical and clinical aspects of the $1918 \mathrm{H} 1 \mathrm{~N} 1$ pandemic in the United States. Virology 2019. 527: 32-37.

[9] Barbara Jester et al. 100 Years of Medical Countermeasures and Pandemic Influenza Preparedness. Am J Public Health.

[10] Burnet F, Clark E. Influenza: a survey of the last 50 years in the light of modern work on the virus of epidemic influenza. Melbourne: MacMillan; 1942.

[11] Marks G, Beatty WK. Epidemics. New York: Scribners; 1976.

[12] Rosenau MJ, Last JM. Maxcy-Rosenau preventative medicine and public health. New York: Appleton-Century-Crofts; 1980.

[13] Crosby A. America's forgotten pandemic. Cambridge (UK): Cambridge University Press; 1989.

[14] Patterson KD, Pyle GF. The geography and mortality of the 1918 influenza pandemic. Bull Hist Med. 1991;65:4-21.

[15] Johnson NPAS, Mueller J. Updating the accounts: global mortality of the 1918-1920 "Spanish" influenza pandemic. Bull Hist Med. 2002;76:105-15.

[16] Johnson NPAS, Mueller J. Updating the accounts: global mortality of the 1918-1920 "Spanish" influenza pandemic. Bull Hist Med. 2002;76:105-15..018; 108: 1469-1472. Doi:10.2105/AJPH.2018.304586.

[17] Crosby AW. America's forgotten pandemic: the influenza of 1918. Cambridge, UK: Cambridge University Press; 19892003.

[18] Patterson KD, Pyle GF. The geography and mortality of the 1918 influenza pandemic. Bull Hist Med. 1991;65:4-21.

[19] Pettit D, Bailie J. A Cruel Wind: Pandemic Flu in America 1918-1920. Murfreesboro, Tennessee: Timberlane Books; 2008.

[20] Influenza 1918 episode (documentary). American Experience. PBS.

[21] Barry, John M. The Great Influenza: The Epic Story of the Greatest Plague in History. Viking Penguin. ISBN 978-0-670-89473-4.

[22] "Mystery pneumonia virus probed in China". BBC News.

[23] Wang C, Horby PW, Hayden FG, Gao GF. A novel coronavirus outbreak of global health concern. Lancet. 2020 Jan 24. pii: S01406736(20)30185-9. https://doi.org/10.1016/S0140-6736(20)30185-9.

[24] Perlman S (February 2020). "Another Decade, Another Coronavirus". The New England Journal of Medicine. 382 (8): 760-762. doi:10.1056/NEJMe2001126. PMC 7121143. PMID 31978944.

[25] Cyranoski D (March 2020). "Mystery deepens over the animal source of coronavirus". Nature. 579 (7797): 18-19. Bibcode:2020Natur.579...18C. doi:10.1038/d41586-020-00548-w. PMID 32127703.

[26] https://www.who.int/emergencies/diseases/novel-coronavirus2019/technical-guidance/naming-the-coronavirus-disease-(COVID2019)-and-the-virus-that-causes-it

[27] "Naming the coronavirus disease (COVID-19) and the virus that causes it". who.int.

[28] "[The epidemiological characteristics of an outbreak of 2019 novel coronavirus diseases (COVID-19) in China]". Zhonghua Liu Xing Bing Xue Za Zhi = Zhonghua Liuxingbingxue Zazhi (in Chinese). 41 (2): 145-151. doi:10.3760/cma.j.issn.0254-6450.2020.02.003. PMID 32064853 .

[29] "WHO Director-General's opening remarks at the media briefing on COVID-19 - 11 March 2020". World Health Organization. 11 March 2020.

[30] "Outbreak of severe acute respiratory syndrome coronavirus 2 (SARSCoV-2): increased transmission beyond China - fourth update" (PDF). European Centre for Disease Prevention and Control. 14 February 2020.

[31] Hui DS, I Azhar E, Madani TA, Ntoumi F, Kock R, Dar O, et al. (February 2020). "The continuing 2019-nCoV epidemic threat of novel coronaviruses to global health-The latest 2019 novel coronavirus 
outbreak in Wuhan, China". Int J Infect Dis. 91: 264-66. doi:10.1016/j.ijid.2020.01.009. PMID 31953166.

[32] "WHO Director-General's opening remarks at the media briefing on COVID-19". World Health Organization (WHO) (Press release). 11 March 2020.

[33] World Health Organization. Coronavirus disease 2019 (COVID-19) Situation Report-89. https://www.who.int/emergencies/diseases/novelcoronavirus-2019/situation-reports/.

[34] Centers for Disease Control and Prevention Types of Influenza Viruses. 2014.

[35] Are we ready for pandemic influenza?Webby RJ, Webster RG Science. 2003 Nov 28; 302(5650):1519-22.

[36] Epidemiology and pathogenesis of influenza. Zambon MC, J Antimicrob Chemother. 1999 Nov; 44 Suppl B:3-9.

[37] Historical perspective--Emergence of influenza A (H1N1) viruses.Zimmer SM, Burke DS, N Engl J Med. 2009 Jul 16; 361(3):279-85

[38] Zhu N, Zhang D, Wang W, et al. A novel coronavirus from patients with pneumonia in China, 2019. N Engl J Med. 2020 Feb 20;382(8):727-33.

[39] Lu R, Zhao X, Li J, et al. Genomic characterisation and epidemiology of 2019 novel coronavirus: implications for virus origins and receptor binding. Lancet. 2020 Feb 22;395(10224):565-74.

[40] Tang X, Wu C, Li X, et al. On the origin and continuing evolution of SARS-CoV-2. Nat Sci.

[41] Lu R, Zhao X, Li J, et al. Genomic characterisation and epidemiology of 2019 novel coronavirus: implications for virus origins and receptor binding. Lancet. 2020 Feb 22;395(10224):565-74.

[42] Yan R, Zhang Y, Li Y, et al. Structural basis for the recognition of the SARS-CoV-2 by full-length human ACE2. Science. 2020 Mar 27;367(6485):1444-8.

[43] Chen Y, Guo Y, Pan Y, et al. Structure analysis of the receptor binding of 2019-nCoV. Biochem Biophys Res Commun. 2020 Feb 17

[44] Coutard B, Valle C, de Lamballerie X, et al. The spike glycoprotein of the new coronavirus 2019-nCoV contains a furin-like cleavage site absent in CoV of the same clade. Antiviral Res. 2020 Feb 10; 176:104742.

[45] Zou X, Chen K, Zou J, et al. Single-cell RNA-seq data analysis on the receptor ACE2 expression reveals the potential risk of different human organs vulnerable to 2019-nCoV infection.

[46] Hanff TC, Harhay MO, Brown TS, et al. Is there an association between COVID-19 mortality and the renin-angiotensin system: a call for epidemiologic investigations. Clin Infect Dis. 2020 Mar 26

[47] Vaughan WT. Influenza: an epidemiological study. Am J Hyg Baltimore. 1921:65-78.

[48] Patterson KD, Pyle GF. The geography and mortality of the 1918 influenza pandemic. Bull Hist Med. 1991; 65:4-21.

[49] Crosby AW. America's forgotten pandemic: the influenza of 1918. Cambridge, UK: Cambridge University Press; 19892003.

[50] Pettit D, Bailie J. A Cruel Wind: Pandemic Flu in America 1918-1920. Murfreesboro, Tennessee: Timberlane Books; 2008.

[51] Simonsen L, Clarke MJ, Schonberger LB, Arden NH, Cox NJ, Fukuda K (July 1998). "Pandemic versus epidemic influenza mortality: a pattern of changing age distribution". The Journal of Infectious Diseases. 178 (1): 53-60. CiteSeerX 10.1.1.327.2581. doi:10.1086/515616. JSTOR 30114117. PMID 9652423.

[52] Novel Coronavirus Pneumonia Emergency Response Epidemiology Team. The epidemiological characteristics of an outbreak of 2019 novel coronavirus diseases (COVID-19) in China [in Chinese] Zhonghua Liu Xing Bing Xue Za Zhi. 2020 Feb 17;41(2):145-51.

[53] Zhan M, Qin Y, Xue X, et al. Death from Covid-19 of 23 health care workers in China. N Engl J Med. 2020 Apr 15.

[54] Dong Y, Mo X, Hu Y, et al. Epidemiological characteristics of 2143 pediatric patients with 2019 coronavirus disease in China. Pediatrics. 2020 Mar 16.

[55] Ludvigsson JF. Systematic review of COVID-19 in children show milder cases and a better prognosis than adults. Acta Paediatr. 2020 Mar 23.

[56] https://www.cdc.gov/flu/pandemic-resources/reconstruction-1918virus.html\#reconstruction.

[57] Zhu N, Zhang D, Wang W, et al. A novel coronavirus from patients with pneumonia in China, 2019. N Engl J Med. 2020. https://doi.org/10.1056/NEJMoa2001017.

[58] Wang W, Xu Y, Gao R, et al. Detection of SARS-CoV-2 in Different Types of Clinical Specimens. Jama. 2020.

[59] Sri Santosh T, Parmar R, Anand H, et al. (April 17, 2020) A Review of Salivary Diagnostics and Its Potential Implication in Detection of Covid-19. Cureus 12(4): e7708. doi:10.7759/cureus.7708.

[60] Wu Y, Guo C, Tang L, et al. Prolonged presence of SARS-CoV-2 viral RNA in faecal samples. The Lancet Gastroenterology \& Hepatology. 2020 .
[61] Chen W, Lan Y, Yuan X, et al. Detectable 2019-nCoV viral RNA in blood is a strong indicator for further clinical severity. Emerging microbes \& infections. 2020;9(1):469-473.

[62] "Spanish flu strikes during World War I". 14 January 2010.

[63] "Q \& A on COVID-19". European Centre for Disease Prevention and Control.

[64] To KK, Tsang OT, Chik-Yan Yip C, Chan KH, Wu TC, Chan JM, et al. (February 2020). "Consistent detection of 2019 novel coronavirus in saliva". Clinical Infectious Diseases. Oxford University Press: ciaa149. doi:10.1093/cid/ciaa149. PMC 7108139. PMID 32047895.

[65] Loh NW, Tan Y, Taculod J, Gorospe B, Teope AS, Somani J, Tan AY (March 2020). "The impact of high-flow nasal cannula (HFNC) on coughing distance: implications on its use during the novel coronavirus disease outbreak". Canadian Journal of Anaesthesia = Journal Canadien d'Anesthesie. doi:10.1007/s12630-020-01634-3. PMC 7090637. PMID 32189218.

[66] "Coronavirus Disease 2019 (COVID-19) - Transmission". Centers for Disease Control and Prevention.

[67] "Reducing risk of microdroplet infection | NHK WORLD-JAPAN News.

[68] "Modes of transmission of virus causing COVID-19: implications for IPC precaution recommendations". who.int.

[69] Li R, Pei S, Chen B, et al. Substantial undocumented infection facilitates the rapid dissemination of novel coronavirus (SARS-CoV2). Science (New York, NY). 2020.

[70] Li Q, Guan X, Wu P, et al. Early Transmission Dynamics in Wuhan, China, of Novel Coronavirus-Infected Pneumonia. N Engl J Med. 2020; https://doi.org/10.1056/NEJMoa2001316.

[71] "New coronavirus stable for hours on surfaces". National Institutes of Health $(\mathrm{NIH})$.

[72] Holshue ML, DeBolt C, Lindquist S, et al. First case of 2019 novel coronavirus in the United States. N Engl J Med 2020; published online Jan 31. https://doi.org/10.1056/NEJMoa2001191.

[73] Chen H, Guo J, Wan C, et al. Clinical characteristics and intrauterine vertical transmission potential of COVID-19 infection in nine pregnant women: a retrospective review of medical records https://doi.org/10.1016/S0140-6736(20)30360-3.

[74] Berglund H, Den s.k. Vol. 15. Allmänna Svenska Läkartidningen; 1918. 'Spanska sjukans' kliniska bild; pp. 1696-701.

[75] Petrén K. Vol. 15. Allmänna Svenska Läkartidningen; 1918. Till influensans, särskilt influensapneumoniernas nosografi och behandling; pp. 1577-600. 1619-30, 1651-69.

[76] Petrén K. Vol. 15. Allmänna Svenska Läkartidningen; 1918. Till influensans, särskilt influensapneumoniernas nosografi och behandling; pp. 1577-600. 1619-30, 1651-69.

[77] The Spanish flu in Uppsala, clinical and epidemiological impact of the influenza pandemic 1918-1919 on a Swedish county,Infection Ecology \&\#x0026; Epidemiology. 2014; 4(),. doi: 10.3402/iee.v4.21528.

[78] Guan WJ, Ni ZY, Hu Y, et al. Clinical Characteristics of Coronavirus Disease 2019 in China. The New England journal of medicine. 2020.

[79] Lauer SA, Grantz KH, Bi Q, et al. The Incubation Period of Coronavirus Disease 2019 (COVID-19) From Publicly Reported Confirmed Cases: Estimation and Application. Annals of internal medicine. 2020.

[80] "Symptoms of Novel Coronavirus (2019-nCoV)". US Centers for Disease Control and Prevention. 10 February 2020.

[81] Velavan, T. P.; Meyer, C. G. (March 2020). "The COVID-19 epidemic". Tropical Medicine \& International Health. 25 (3): 278-280. doi:10.1111/tmi.13383. PMID 32052514.

[82] "Coronavirus Disease 2019 (COVID-19) - Transmission". Centers for Disease Control and Prevention. 17 March 2020.

[83] Zou L, Ruan F, Huang M, et al. SARS-CoV-2 Viral Load in Upper Respiratory Specimens of Infected Patients. The New England journal of medicine. 2020;382(12):1177-1179.

[84] Liu Y, Yan LM, Wan L, et al. Viral dynamics in mild and severe cases of COVID-19. The Lancet Infectious diseases. 2020.

[85] Huang C, Wang Y, Li X, et al. Clinical features of patients infected with 2019 novel coronavirus in Wuhan, China. Lancet. 2020; pii: S0140-6736(20)30183-5. https://doi.org/10.1016/S01406736(20)30183-5.

[86] "Symptoms of Novel Coronavirus (2019-nCoV)". US Centers for Disease Control and Prevention. 10 February 2020.

[87] Chen N, Zhou M, Dong X, et al. Epidemiological and clinical characteristics of 99 cases of 2019 novel coronavirus pneumonia in Wuhan, China: a descriptive study. Lancet (London, England). 2020;395(10223):507-513.

[88] Wu C, Chen X, Cai Y, et al. Risk Factors Associated With Acute Respiratory Distress Syndrome and Death in Patients With Coronavirus Disease 2019 Pneumonia in Wuhan, China. JAMA Intern Med. 2020. 
[89] Yang X, Yu Y, Xu J, et al. Clinical course and outcomes of critically ill patients with SARS-CoV-2 pneumonia in Wuhan, China: a singlecentered, retrospective, observational study. The Lancet Respiratory medicine. 2020.

[90] Zhou F, Yu T, Du R, et al. Clinical course and risk factors for mortality of adult inpatients with COVID-19 in Wuhan, China: a retrospective cohort study. Lancet (London, England). 2020.

[91] Pan L, Mu M, Ren HG, et al. Clinical characteristics of COVID-19 patients with digestive symptoms in Hubei, China: a descriptive, crosssectional, multicenter study. Am J Gastroenterol. 2020.

[92] Giacomelli A, Pezzati L, Conti F, et al. Self-reported olfactory and taste disorders in SARS-CoV-2 patients: a cross-sectional study. Clinical Infectious Diseases. 2020.

[93] Iacobucci G (March 2020). "Sixty seconds on anosmia". BMJ. 368: m1202. doi:10.1136/bmj.m1202. PMID 32209546.

[94] Vito Fanelli, Marco Fiorentino, et al. Acute kidney injury in SARSCoV-2 infected patients, Critical Care volume 24, Article number: 155 (2020),bmc.

[95] Ronco C, Navalesi P, Vincent JL. Coronavirus epidemic: preparing for extracorporeal organ support in intensive care. Lancet Respir Med $2020 ; \quad 8(3): \quad 240-241 . \quad$ doi: https://doi.org/10.1016/S22132600(20)30060-6.

[96] Barry JM (January 2004). "The site of origin of the 1918 influenza pandemic and its public health implications". Journal of Translational Medicine. 2 (1): 3. doi:10.1186/1479-5876-2-3. PMC 340389. PMID 14733617.

[97] Patterson KD, Pyle GF (1991). "The geography and mortality of the 1918 influenza pandemic". Bulletin of the History of Medicine. 65 (1) 4-21. PMID 2021692.

[98] Knobler S, Mack A, Mahmoud A, Lemon S, eds. (2005). "1: The Story of Influenza". The Threat of Pandemic Influenza: Are We Ready? Workshop Summary (2005). Washington, DC: The National Academies Press. pp. 60-61.

[99] Morris, Denise E.; Cleary, David W.; Clarke, Stuart C. (2017). "Secondary Bacterial Infections Associated with Influenza Pandemics". Frontiers in Microbiology. 8 . doi:10.3389/fmicb.2017.01041. ISSN 1664-302X

[100]Vilensky JA, Foley P, Gilman S (August 2007). "Children and encephalitis lethargica: a historical review". Pediatric Neurology. 37 (2): 79-84. doi:10.1016/j.pediatrneurol.2007.04.012. PMID 17675021

[101]Novel Coronavirus Pneumonia Emergency Response Epidemiology T. [The epidemiological characteristics of an outbreak of 2019 novel coronavirus diseases (COVID-19) in China]. Zhonghua Liu Xing Bing Xue Za Zhi. 2020;41(2):145-151.

[102] Madjid M, Safavi-Naeini P, Solomon SD, et al. Potential effects of coronaviruses on the cardiovascular system: a review. JAMA Cardiol. 2020 Mar 27.

[103] Ye Q, Wang B, Mao J. Cytokine storm in COVID-19 and treatment. J Infect. 2020 Apr 10

[104] Sun P, Qie S, Liu Z, et al. Clinical characteristics of 50466 hospitalized patients with 2019-nCoV infection. J Med Virol. 2020 Feb 28

[105] Dong Y, Mo X, Hu Y, et al. Epidemiological characteristics of 2143 pediatric patients with 2019 coronavirus disease in China. Pediatrics. 2020 Mar 16.

[106] Xu L, Liu J, Lu M, et al. Liver injury during highly pathogenic human coronavirus infections. Liver Int. 2020 Mar 14.

[107] Ranucci M, Ballotta A, Di Dedda U, et al. The procoagulant pattern of patients with COVID-19 acute respiratory distress syndrome. J Thromb Haemost. 2020 Apr 17

[108] Klok FA, Kruip MJHA, van der Meer NJM, et al. Incidence of thrombotic complications in critically ill ICU patients with COVID-19. Thromb Res. 2020 Apr 10.

[109] Oxley TJ, Mocco J, Majidi S, et al. Large-vessel stroke as a presenting feature of Covid-19 in the young. N Engl J Med. 2020 Apr 28.

[110] Zhao H, Shen D, Zhou H, et al. Guillain-Barré syndrome associated with SARS-CoV-2 infection: causality or coincidence? Lancet Neurol. 2020 May;19(5):383-4.

[111] Rodriguez-Morales AJ, Cardona-Ospina JA, Gutiérrez-Ocampo E, et al. Clinical, laboratory, and imaging features of COVID-19: a systematic review and meta-analysis. Travel Med Infect Dis. 2020 Mar 13:101623.

[112] Chen N, Zhou M, Dong X, et al. Epidemiological and clinical characteristics of 99 cases of 2019 novel coronavirus pneumonia in Wuhan, China: a descriptive study. Lancet. 2020 Feb 15;395(10223):507-13.

[113] Huang C, Wang Y, Li X, et al. Clinical features of patients infected with 2019 novel coronavirus in Wuhan, China. Lancet. $2020 \mathrm{Feb}$ 15;395(10223):497-506.

[114] Huang C, Wang Y, Li X, et al. Clinical features of patients infected with 2019 novel coronavirus in Wuhan, China. Lancet. $2020 \mathrm{Feb}$ 15;395(10223):497-506.
[115] Zou L, Ruan F, Huang M, et al. SARS-CoV-2 Viral Load in Upper Respiratory Specimens of Infected Patients. The New England journal of medicine. 2020;382(12):1177-1179.

[116] Guo L, Ren L, Yang S, et al. Profiling Early Humoral Response to Diagnose Novel Coronavirus Disease (COVID-19). Clinical infectious diseases: an official publication of the Infectious Diseases Society of America. 2020.

[117] Beach, Brian; Ferrie, Joseph P.; Saavedra, Martin H. (2018). "Fetal shock or selection? The 1918 influenza pandemic and human capital development". nber.org. doi:10.3386/w24725.

[118] Almond, Douglas "Is the 1918 Influenza Pandemic Over? Long-Term Effects of In Utero Influenza Exposure in the Post-1940 U.S Population". Journal of Political Economy. 114 (4): 672-712 doi:10.1086/507154. ISSN 0022-3808.

[119] "Here Comes the Coronavirus Pandemic: Now, after many fire drills, the world may be facing a real fire". Editorial. The New York Times. 29 February 2020.

[120] "COVID-19 Educational Disruption and Response". UNESCO. 4 March 2020.

[121] Rico-AvelloC. Historia de la sanidad Española (1900-1935),1969 Madrid Gimenez.

[122] Echeverri B. La gripe española: la pandemia de 1918-1919, Coleccion Monografias (132), 1993 Madrid Centro de Investigaciones Sociologicas.

[123] Bertran JL, Historia de las epidemias en España y sus colonias (13481919), 2006MadridLa Esfera de los Libros.

[124] Spinney L (29 March 2020). "Coronavirus vaccine: when will it be ready?". The Guardian. ISSN 0261-3077.

[125] "Prevention \& Treatment". US Centers for Disease Control and Prevention. 15 February 2020. Archived from the original on 15 December 2019

[126] "Coronavirus disease (COVID-19) advice for the public: When and how to use masks". World Health Organization.

[127] Lu CW, Liu XF, Jia ZF. 2019-nCoV transmission through the ocular surface must not be ignored. Lancet. 2020; pii: S0140-6736(20)303135. https://doi.org/10.1016/S0140-6736(20)30313-5.

[128] Thordarson, Pall (12 March 2020). "The science of soap - here's how it kills the coronavirus | Pall Thordarson". The Guardian. ISSN 02613077.

[129] Kampf G, Todt D, Pfaender S, Steinmann E (March 2020). "Persistence of coronaviruses on inanimate surfaces and thei inactivation with biocidal agents". The Journal of Hospital Infection 104 (3): 246-251.

[130] "Coronavirus Disease 2019 (COVID-19)". US Centers for Disease Control and Prevention.

[131] "Coronavirus disease (COVID-19) advice for the public: When and how to use masks". World Health Organization.

[132] "Coronavirus Disease 2019 (COVID-19): If You Have Animals". cdc.gov.

[133] Sandee LaMotte, Lions, tigers and house cats: You won't catch coronavirus from felines, experts say, 6 April 2020, CNN

[134] suppl 1-32. Vol. 21. Allmänna Svenska Läkartidningen; 1924 Influensakommitens rapport; p. 9 .

[135] Hatchett RJ, Mecher CE, Lipsitch M. Public health interventions and epidemic intensity during the 1918 influenza pandemic. Proc Natl Acad Sci U S A. 2007; 104:7582-7.

[136] Grönstedt K. Allmänna Svenska läkartidningen; 1919. Spanska sjukans behandling; pp. 19-21.

[137] Bjerner B. Allmänna Svenska Läkartidningen; 1919. Antidifteri serum mot influenza; pp. 103-105.

[138] Engelsson H. Allmänna Svenska Läkartidningen; 1919. Neosalvarsan och kvicksilver någon skyddande effekt mot influenza? pp. 362-364.

[139] Wållgren C. Spanska sjukan vid sahlgrenska sjukhuset. [The Spanish flu at the Sahlgrenska Hospital]. Hygiea. 1920; 82:257-70.

[140] Starko KM. Salicylates and pandemic influenza mortality, 1918-1919 pharmacology, pathology, and historic evidence. Clin Infect Dis. 2009; 49:1405-10.

[141] "Q\&A on coronaviruses". World Health Organization. 11 February 2020.

[142] A randomized, open-label, blank-controlled trial for the efficacy and safety of lopinavir-ritonavir and interferon-alpha $2 b$ in hospitalization patients with novel coronavirus infection. Available from www.chictr.org.cn/showprojen.aspx?proj=48684

[143] Bin Cao, M.D., Yeming Wang, M.D., Danning Wen, M.D., et al.A tria of Lopinavir-Ritonavir in Adults Hospitalized with Severe Covid-19. N Engl J Med. DOI: 10.1056/NEJMoa2001282.

[144] Holshue ML, DeBolt C, Lindquist S, et al. First case of 2019 novel coronavirus in the United States. N Engl J Med 2020; published online Jan 31. https://doi.org/10.1056/NEJMoa2001191. 
[145] Kui L, Fang YY, Deng Y, et al. Clinical characteristics of novel coronavirus cases in tertiary hospitals in Hubei Province. Chin Med J (Engl). 2020. https://doi.org/10.1097/CM9.0000000000000744.

[146] Richardson P, Griffin I, Tucker C, et al. Baricitinib as potential treatment for 2019-nCoV acute respiratory disease. Lancet. $2020 \mathrm{Feb}$ 4. pii: S0140-6736(20)30304-4. https://doi.org/10.1016/S01406736(20)30304-4.

[147] "Caring for Yourself at Home". Centers for Disease Control and Prevention. 11 February 2020.

[148] Paton N.I., Lee L., Xu Y., Ooi E.E., Cheung Y.B., Archuleta S. Chloroquine for influenza prevention: a randomised, double-blind, placebo controlled trial. Lancet Infect Dis. 2011 Sep;11(9):677-683.

[149] Vigerust D.J., McCullers J.A. Chloroquine is effective against influenza A virus in vitro but not in vivo. Influenza Other Respir Viruses. 2007; 1:189-192.

[150] Wang M., Cao R., Zhang L., Yang X., Liu J., Xu M. Remdesivir and chloroquine effectively inhibit the recently emerged novel coronavirus (2019-nCoV) in vitro. Cell Res. 2020.

[151] Colson P., Rolain J.M., Lagier J.C., Brouqui P., Raoult D. Chloroquine and hydroxychloroquine as available weapons to fight COVID-19. Int J Antimicrob Agents. 2020 Mar 4:105932.

[152] Ahn JY, Sohn Y, Lee SH, et al. Use of Convalescent Plasma Therapy in Two COVID-19 Patients with Acute Respiratory Distress Syndrome in Korea. J Korean Med Sci. 2020 Apr 13;35(14):e149. doi: 10.3346/jkms.2020.35.e149.

[153] Chen L, Xiong J, Bao L, Shi Y. Convalescent plasma as a potential therapy for COVID-19. Lancet Infect Dis. 2020;20(4):398-400.

[154] Spinney L, "Coronavirus vaccine: when will it be ready?". The Guardian. ISSN 0261-3077.

[155] Huaxia. WHO says vaccines against novel coronavirus 18 months away, pushes global research. 2020. Xinhuanet, Feb 12, 2020 http://www.xinhuanet.com/english/2020-02/12/c_138777886.htm.

[156] "WHO Director-General's opening remarks at the media briefing on COVID-19 - 11 March 2020". World Health Organization. 11 March 2020. 